\title{
The Eurasian otter Lutra lutra (Linnaeus, 1758) in Portugal
}

\author{
La nutria eurasiática Lutra lutra (Linnaeus, 1758) en Portugal \\ Lutra lutra (Linnaeus, 1758) igaraba eurasiarra Portugalen
}

\author{
Nuno M. Pedroso ${ }^{1 *}$, Teresa Sales-Luís ${ }^{1} \&$ Margarida Santos-Reis ${ }^{1}$ \\ ${ }^{1}$ Centro de Biologia Ambiental, Faculdade de Ciências, Universidade de Lisboa, 1749-016 Lisboa, Portugal. \\ * Corresponding author: nmpedroso@fc.ul.pt
}

\begin{abstract}
Eurasian otters Lutra lutra (Linnaeus, 1758) are known to occur in Portugal since historical times but only in 1995 a national survey confirmed the species' broad distribution. Since then, studies and projects conducted in different aquatic environments indicate the existence of a healthy population, the availability of vegetation cover, water and prey being the major factors explaining otter presence. Spraint analyses showed that fish, amphibians and American crayfish form the bulk of otter diet. Due to increasing knowledge about the species ecology and distribution, in 2005, otter status was changed, from "Insufficiently Known" to "Least Concern". Recent main lines of investigation have become increasingly threat specific and include: otter use of reservoirs, man-otter conflicts (fish farming), otters and non-native species interactions (prevalence in otter diet; competition with American mink) and otters and antimicrobial resistant bacteria. Destruction of the riparian vegetation commonly associated with dam construction, river regulation, agricultural expansion, gravel and sand extraction, as well as the development of tourism in, costal and wetland areas are still potential threats to otter populations. Overall, in the near future otters seem safe from major disrupting settings but otter conservation and effective management are still an important issues. This is especially relevant in the Iberian Peninsula, as climate changes are expected to reduce suitable otter habitats. Knowledge gaps and future research needs are also addressed in this chapter.
\end{abstract}

KEYWORDS: Conservation, otter, Portugal, research, status.

\section{RESUMEN}

La presencia de la nutria euroasiática Lutra lutra (Linnaeus, 1758) en Portugal se conoce desde tiempos históricos, pero no fue hasta 1995 cuando gracias a un sondeo nacional se confirmó la amplia distribución de la especie. Desde entonces, se han realizado múltiples estudios y proyectos en diferentes ambientes acuáticos que indican la existencia de una población sana, siendo la disponibilidad de cobertura vegetal, el agua y las presas los principales factores que explican la presencia de la nutria. Los análisis de excrementos mostraron que los peces, los anfibios y el cangrejo de río americano forman el grueso de la dieta de la nutria. Debido al aumento de los conocimientos sobre la ecología y distribución de la especie, en 2005, el estado de la nutria pasó de "Insuficientemente Conocida" a "Preocupación Menor". Recientes líneas de investigación se han dado a conocer un aumento de amenazas específicas que incluyen: el uso de los embalses por parte de las nutrias, los conflictos hombre- nutria (acuicultura), y las interacciones entre las nutrias y las especies no nativas (prevalencia en la dieta de la nutria, la competencia con el visón americano) y las nutrias y bacterias resistentes a los antimicrobianos. La destrucción de la vegetación de ribera asociada comúnmente con la construcción de presas, la regulación de caudales, la expansión agrícola, la extracción de grava y arena, así como el desarrollo del turismo en zonas costeras y humedales son potenciales amenazas a las poblaciones de nutria. En general, a corto plazo las nutrias parecen a salvo de las principales afecciones pero su conservación y su correcta gestión siguen siendo un problema importante. Esto es especialmente relevante en la Península Ibérica, pues se espera que los cambios climáticos reduzcan los hábitats adecuados para la nutria. En esta capítulo se abordan también temas como la falta de datos existentes y las necesidades de investigación futuras.

PALABRAS CLAVE: Conservación, nutria, Portugal, investigación, status.

\section{LABURPENA}

Lutra lutra (Linnaeus, 1758) igaraba eurasiarraren presentzia antzinatik ezagutzen dugu, baina 1995. urtean egindako Estatu mailako zundaketari esker baieztatu zuten espeziea toki zabalean banatuta dagoela. Ordutik uretako hainbat ingurunetan egin izan diren ikerketa eta proiektu ugariek agerian utzi dute populazio osasuntsua dagoela bertan eta igarabaren presentzia ahalbidetzen duten faktore nagusiak honako hauek dira: estaldura begetala, ura eta harrapakinak izatea. Gorotzen azterketek bistaratu zutenez, igarabaren dietako elementu nagusiak honako hauek dira: arrainak, anfibioak eta ibai-karramarro amerikarra. Espeziearen banaketari eta ekologiari buruzko ezagutzak ugaritu izanaren ondorioz, 2005ean, igarabaren egoera "ez da behar adina ezaguna" izatetik, "kezka txikiagoa" egoerara aldatu zen. Azken ikerketaildoen arabera, ordea, mehatxu espezifikoak ugaritu egin dira eta horien artean daude hauek: igarabek urtegiak erabiltzea, gizakia-igarabaren arteko gatazkak (akuikultura), igaraben eta bertakoak ez diren espezieen arteko interakzioak (igarabaren dietan nagusi dira, bisoi amerikarrarekin lehia), igarabak eta mikrobianoen aurkakoekiko erresistenteak diren bakterioak. Ibaiertzeko landaredia suntsitzea da igarabaren populazioetarako mehatxu nagusietako bat eta hori, gehienetan, honako hauekin lotuta dago: urtegiak eraikitzea, emariak erregulatzea, nekazaritzaren hedapena, legarra eta hondarra ateratzea eta hezeguneetako eta kostaldeko turismoa garatu izana. Oro har, epe laburrera begira, igarabak asaldura nagusietatik salbu daudela ematen du, baina haien behar bezalako kudeaketa eta kontserbazioa oraindik ere arazo handia da. Hori bereziki esanguratsua da iberiar penintsulan; izan ere, klima-aldaketek igarabarako egokiak diren habitatak gutxituko dituztela aurrez ikusi dute. Kapitulu honetan, gainera, beste gai batzuk ere landuko ditugu: eskuragarri dauden datuak falta direla eta etorkizunerako ikerketen beharrak, esate baterako. 


\section{DISTRIBUTION AND STATUS}

Eurasian otters Lutra lutra (Linnaeus, 1758) are known in Portugal since historical times (for a review see Santos-Reis et al., 1995). In 1863 this predator was mentioned as frequent in all Portuguese rivers (Bocage, 1863), but some decades after the species was described as confined to the north of the country (Seabra, 1900) and soon after facing extinction (Seabra, 1924). The lack of information thereafter, and the severe decline of the species in most of its original European range (MacDonald \& Mason, 1994), leaded Reuther (1977) to consider the species as extinct in Portugal in his overview about the species status in Europe. At the same time the first record of a coastal population in the southwest rocky coast of Portugal was published in a national bulletin (Simões, 1977) and soon after the otter was proven to be present in most of the North and Central part of the country (Ferrand-Almeida, 1980; Macdonald \& Mason, 1982).

In the 1970's the socio-economic importance of rivers for irrigation, with high demands of water for crops such as rice and tomatoes (e.g. lower stretches of Mondego, Tejo and Sado rivers), and fishing (e.g. Mondego river) increased both hunting pressure (by both hunters and fishermen) and indirect human interference through water pollution, river regulation and habitat destruction (SimõesGraça \& Ferrand-Almeida, 1983; Macdonald \& Mason, 1982). Although in Portugal the species is protected by law since 1974 (DL 354A/74 August 14th) and trade is forbidden since 1973 (Washington Convention - CITES), the lack of law enforcement and control allowed illegal hunting to continue (trapping for fur and embalmment and persecution for sport, with packs of hounds, or to protect fish stocks) (Santos-Reis, 1983). Embalmed specimens were commonly seen in shops, pelts were sold in regional fairs and otters were said to be shot for meat consumption on the Sado river (Santos-Reis, 1983).

Industrial underdevelopment and low use of pesticides (Macdonald \& Mason, 1982) might have prevented the otter population crash recorded in other more industrialized countries. Nevertheless, intense urban and industrial contamination in the rivers crossing the major cities (Lisboa and Porto) (Santos-Reis, 1983) and technological developments for aerial dispersal of pesticides in rice-growing areas impacted both local fish communities (Simões-Graça \& Ferrand-Almeida, 1983) and, probably, otter populations.

Since the 1980's, contradictory information about the species distribution and status, and the international conservation concerns and efforts in view of the severe decline faced by the species at the European level, has stirred the scientific and conservation community to study the species. As a result, otters were found to be frequent in most Portuguese rivers, although, lacking a standardised monitoring protocol, data were mostly scattered over space and time (Ferrand-Almeida, 1980; Macdonald \& Mason, 1982; Santos-Reis, 1983; Simões-Graça \& Ferrand-Almeida, 1983; Trindade, 1987, 1989, 1991; Beja, 1989a, b).
Given the paucity of scientifically based data, the otter was listed as "Insufficiently Known" in the Portuguese Red Data Book of Terrestrial Vertebrates and recommendations were made to further study the species (SNPRCN, 1990). A major step forward a deeper knowledge of otter distribution in the country was the nation-wide survey promoted in 1995 by the Institute for the Conservation of Nature and Forests (former Instituto da Conservação da Natureza). This survey followed the International Union for Conservation of Nature (IUCN) Otter Specialist Group (OSG) protocol (Foster-Turley et al., 1990; Reuther et al., 2000) and allowed to map otter distribution according to a $10 \times 10 \mathrm{~km}$ UTM grid system (MacDonald, 1983). The survey confirmed the broad distribution of the otter across Portugal, except for the surroundings of the two major cities of the country and an industrial area (Setúbal) to the south of Lisboa (Fig. 1) (Trindade et al., 1998).

Concurrently to, or following the national survey, several short-term research projects focused on otters and resulted in an increasing number of papers and unpublished reports (mostly thesis) carried out in different aquatic environments: rivers (Florêncio, 1994; Afonso, 1997; Chambel, 1997a; Freitas, 1999; Lopes, 1999; Bernardo, 2008), intermittent streams (Matos, 1999; Marques, 2010; Salgueiro, 2009; Sales-Luís et al., 2012; Quaglietta et al., 2012, 2013), rice fields (Trindade, 2002), high altitude lagoons (Sousa, 1995), small reservoirs (Basto,

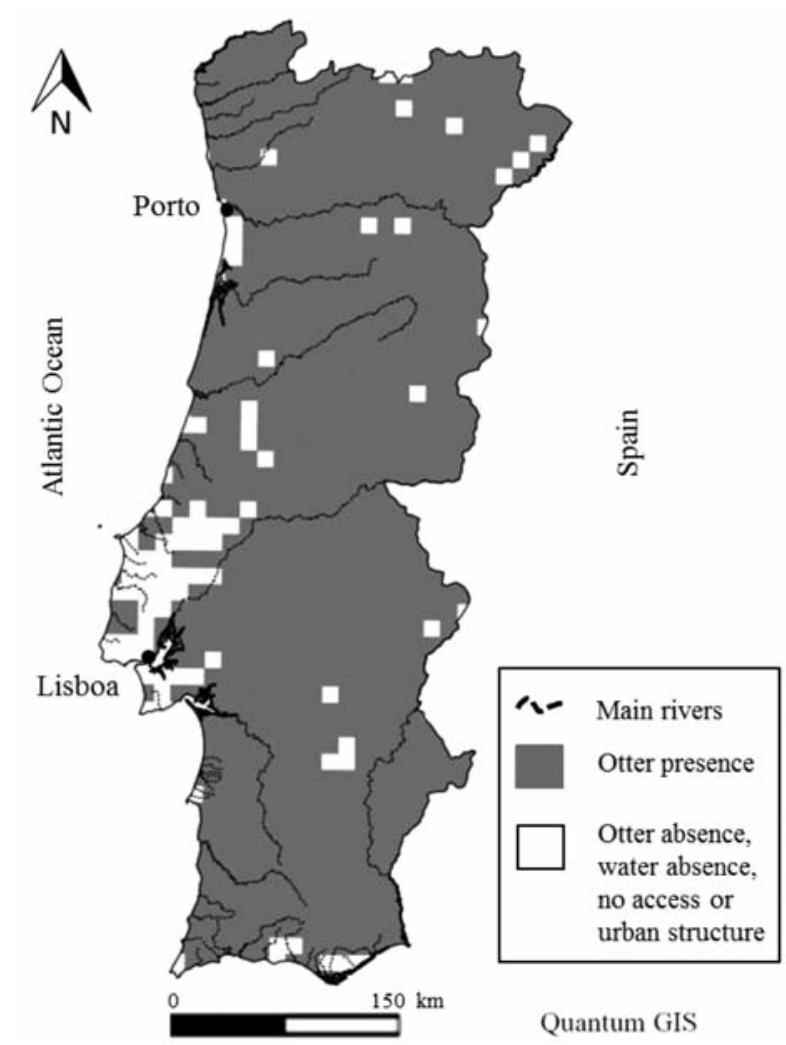

Fig. 1. - Otter distribution in Portugal (10×10 km UTM, adapted from Trindade et al., 1998)

Fig. 1. - Distribución de la nutria en Portugal (10 x 10 km UTM, adaptado de Trindade et al., 1998). 
2006; Basto et al., 2011), large dams (Pedroso, 1997, 2012; Pedroso \& Santos-Reis, 2006, 2009; Pedroso et al., 2007; Sales-Luís et al., 2007; Santos et al., 2008; Pedroso, 2012; Pedroso et al., 2013), estuaries (Campos, 1993; Trigo, 1994; Trindade, 1996; Freitas et al., 2007; SalesLuís et al., 2009; Sales-Luís, 2011) and sea coast environments (Beja, 1989a; Beja, 1992; Gomes, 1998; Pedrosa, 2000; Cerqueira, 2005).

Although available data for Portugal suggest that otters are abundant, few attempts have been made to quantify population density and also sound abundance assessments are scarce. Existing data refer to a few capture campaigns, carried out for translocation or research on otter behaviour.

The first species-oriented trapping campaign was conducted by Beja (1995a) in a costal habitat, where 4 female otters were captured. Following this attempt another campaign was put in place in 2000 in the area to be flooded by Alqueva large dam (River Guadiana, Southeast Alentejo). The aim was to capture 10 adult otters to be translocated to Catalonia (Spain) for a reintroduction program; 19 otters were captured with a trapping effort of 2,500 leghold trap/nights (Santos-Reis et al., 2003). According to the trapping experience of the reintroduction team, this capture success was high and hence indicative of otter abundance (Deli Saavedra, pers. com.).

In the frame of a European project analysing the impact of predation by wildlife on fisheries, molecular spraint analyses, using 5 microsatellites, revealed that the number of otters visiting 14 fish farms located in the Sado river estuary varied between 1 and 7 individuals per farm; overall, a minimum number of 15 individuals were identified in a $100 \mathrm{~km}^{2}$ wide area (Sales-Luís et al., 2009), a value similar to that found in a pond area for raising carps Cyprinus carpio Linnaeus, 1758 in Central Europe (Kranz, 1994).

Quaglietta et al. $(2012,2013)$ used both radiotracking and genetic analyses to assess the otter social structure at a fine spatio-temporal scale in the Alentejo region (southern Portugal, 2007-2010). During that period, 51 individual genotypes were described by 19 microsatellites and 7 young otters were radiotracked ( 2 female, 5 male). Both genetic and field data suggested male-biased dispersal and female philopatry.

The overall result of these studies indicated the existence in Portugal of a healthy otter population. As a consequence, since 2005 the otter has been downgraded to the "Least Concern" IUCN category (Cabral et al., 2005).

\section{ECOLOGY AND CONSERVATION Diet and habitat studies}

Undoubtedly spraints can reveal what otters eat and most Portuguese studies, although sometimes providing local/regional data on the distribution pattern and habitat preferences of the mustelid, focused on its food habits (e.g. Gomes et al., 1989; Beja,1989a,1991,1995a,b,1996a,b,c; Florêncio, 1993, 1994; Trigo, 1994; Gomes, 1998; Farinha,
1995; Sousa, 1995; Chambel, 1997a,b; Pedroso, 1997 Azinheira, 1998; Freitas, 1999; Lopes, 1999; Matos, 1999; Silva, 1999; Pedrosa, 2000; Barrinha, 2002; Magalhães et al., 2002; Trindade, 2002; Garcia, 2005; Novais, 2005; Pedroso \& Santos-Reis, 2006; Freitas et al., 2007; Marques et al., 2007; Sales-Luís et al., 2007; Marques, 2010; Basto et al., 2011; Pedroso et al., 2013). Hence the otter diet in the different Portuguese aquatic habitats is currently well known.

Available information on otter diet in Portugal was reviewed in 2008 (Clavero et al., 2008), yielding a total of 111 study sites from 52 different locations. As expected, fish occurred in the otter diet in all locations, but also crustaceans, particularly the American crayfish Procambarus clarkii (Girard, 1852) (Fig. 2), and amphibians showed a preponderant role in the species diet, being present in 80 to $90 \%$ of the sampled sites (Clavero et al., 2008).

When expressed in terms of percentage of occurrence $[$ P.O. $=$ (total number of a particular prey item/sum of all prey items)x100], these items form, respectively, $50 \%, 35 \%$ and $7 \%$ of otter diet, while all other prey items fall below $1 \%$. A strong variation is however observed in both space and time: the American crayfish can reach values as high as 96\%. (Sado river rice-fields; Trindade, 2002) and amphibians can represent up to $54 \%$ of the diet (high altitude lagoons of Serra da Estrela; Sousa, 1995). In Mediterranean habitats, fish availability for otters can show sharp seasonal variation, forcing it to switch on alternative prey (e.g. Magalhães et al., 2002, 2007; Clavero et al., 2008; Ruiz-Olmo et al., 2009; Marques, 2010). In summer, high air temperatures and drought cause a shortage of surface waters with fish becoming confined to pool refugia and small reaches maintaining flowing waters, where they are at high risk of mortality from desiccation, predation or anoxia (Magalhães et al., 2007). As a consequence, the American crayfish, which can more easily face large periods of water shortage, in summer may become a more profita-

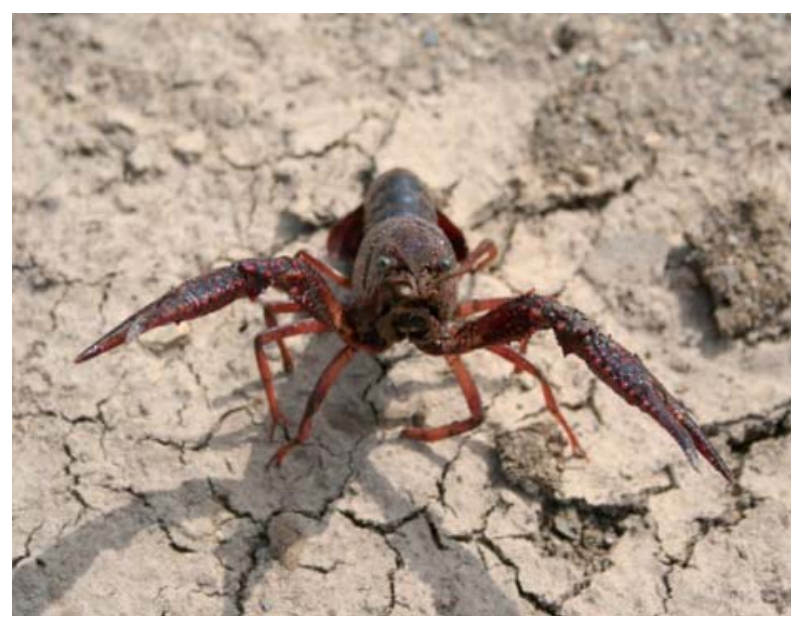

Fig. 2. - American crayfish Procambarus clarkii, an otter common prey in Portugal (photo: Nuno M. Pedroso).

Fig. 2. - Cangrejo rojo, presa común de la nutria en Portugal (foto: Nuno M. Pedroso). 
ble to otter than fish (e.g. Marques, 2010; Basto et al., 2011). Such a feeding adaptability suggests that the otter is better described as an opportunist predator rather than as a specialist (e.g. Sales-Luís et al., 2007).

Although otters are widespread in all aquatic habitats of Portugal, several studies based on sprainting activity as an index of habitat use by otters showed that the availability of riparian vegetation cover, refuges, and, specially, water and prey are the main factors explaining otter distribution. Otters probably prefer large streams with good vegetation cover as these are more likely to maintain freshwater during the dry periods. Otters inhabiting coastal areas use both marine and freshwater resources with otters finding refuge in small coastal streams but feeding largely in the costal and open sea (Beja, 1995a). Coastal populations also depend on fresh water for washing the salt from the hair coat, as to preserve its insulating capacity, and probably for drinking (Beja, 1992; Kruuk, 2006).

\section{Territories and otter numbers}

Home range size and habitat preferences of otters are largely unknown due to the difficulty in capturing and radio-tracking otters. The works of Beja (1995a, 1996c), Bernardo (2008) and Quaglietta et al. (2013) are exceptions and provide some insights in two contrasting aquatic habitats. Beja radiotacked otters in a coastal area, recording home ranges between 4 and $15 \mathrm{~km}$ wide (Beja, 1996c) and otters spent most of daytime in restsites, devoting only $18 \%$ of the $24 \mathrm{~h}$ period to hunting or other activities. More recently, otters have been captured near Évora (Southeast Alentejo), an area characterised by several small streams and a few small reservoirs. Available results indicate that average home range size was $35.6 \mathrm{~km}$ of stream for males and $15.9 \mathrm{~km}$ for females, with core areas of 8.0 and $4.5 \mathrm{~km}$, respectively (Bernardo, 2008). Quaglietta et al. (2013) reported an average home range size of $17 \mathrm{~km}$ for females and an average dispersal distance of $20.8 \mathrm{~km}$ for males. These results agree with Spanish data (Palomo et al., 2007).

\section{CURRENT LINES OF RESEARCH}

\section{Otters and dams}

Dam construction, by changing a flowing river in a deep still water body, is considered to have a great impact on river habitats (Robitaile \& Laurence, 2002), their connectivity (Michelot \& Bendelé, 1995), prey availability and vulnerability (Houston \& McNamara, 1994; Kruuk, 1995) and, finally, otter populations (MacDonald \& Mason, 1994; Ruiz-Olmo et al., 2001; Pedroso, 2012). Possible ecological and conservation implications are especially relevant in Mediterranean areas, where the building of large dams is still ongoing for water management, and streams suffer several other pressures (human and climatic - the current scenario of climate change affects the riverine systems mostly by extending the drought period). Nevertheless, in Portugal, since 1996 otters have been shown to use these altered habitats.

Particularly, several studies showed that otters use both large (Pedroso et al., 2007; Santos et al., 2008; Pedroso, 2012; Pedroso et al., 2013) and small reservoirs (Basto et al., 2011), mainly as foraging grounds (Pedroso and Santos-Reis, 2006; Sales-Luis et al., 2007; Basto et al., 2011). In large reservoirs, the fish community is strongly dominated by non-native species that are largely available to otters throughout the year and, accordingly, represent the bulk of otter diet (Pedroso, 2012).

Reservoirs seem to constitute an "attraction point" for otters particularly in drought periods when rivers and streams dry up (e.g. Prenda et al., 2001; Pedroso and SantosReis, 2006; Pedroso, 2012). However, the negative association found between the use of medium and small reservoirs and the length of watercourses with developed riparian vegetation in the surrounding areas may reflect the otter preference for best-preserved streams and rivers (Basto et al., 2011; Pedroso, 2012). Nevertheless, small reservoirs may have a lower negative impact on otters than large ones as they do not involve the loss of large areas of natural habitat, have negligible effects on water flow regimes and do not constrain otter fishing ability due to their smoother margins and shallow waters with respect to large reservoirs (Fig. 3).

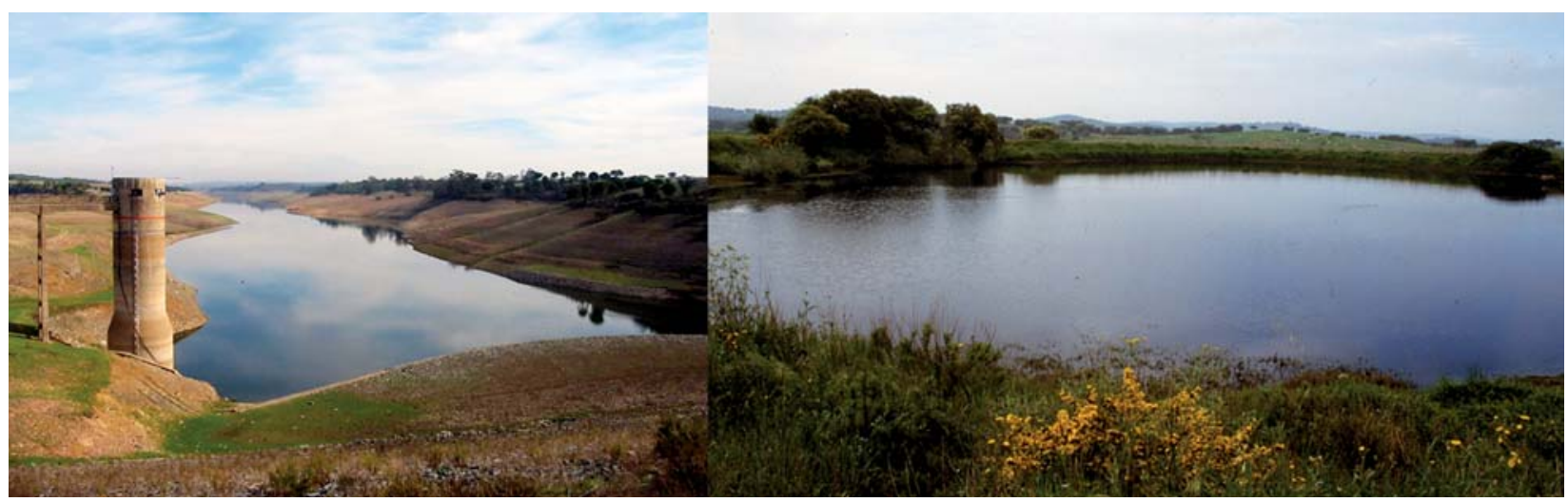

Fig. 3 - Large reservoir (Vale do Gaio dam) - left; small reservoir (Serra de Monfurado area) - right (both in South Portugal) (photos: Nuno M. Pedroso).

Fig. 3. - Gran embalse (Vale do Gaio) - a la izquierda; pequeño embalse (zona de la Serra de Monfurado) - a la derecha (ambos en el sur de Portugal) (fotos: Nuno M. Pedroso). 
A recent study (Pedroso et al., 2013) assessed how otter responded over time to environmental changes imposed by the construction of a large dam in SE Portugal. Otter distribution was monitored from 2000 to 2006. Otter were widespread prior to dam construction, decreased during deforestation, and particularly during the flooding phase, and recovered during the post flooding phase, although not to the level recorded prior to dam construction. After the construction of the dam, otter diet became based on non-native prey species and monitoring revealed a decrease in habitat connectivity, bankside vegetation cover, breeding and foraging grounds, throughout the reservoir.

Although past and current studies suggest that large dam reservoirs are suboptimal habitats for otters when compared to rivers and streams, for widely distributed and healthy populations, such as the one occurring in Portugal, dams are less concerning and, if followed by conservation measures and management actions, they may even constitute a habitat complement to natural riverine systems.. Nevertheless, the destruction of riverine systems remains a matter of major concern, especially in areas of otter population fragility and/or instability.

\section{Man-otter conflicts}

Direct persecution and hunting of otters still happens, for the fur and legally in some countries (e.g. Russia), but is otherwise less significant and related to the species being considered a threat to fish populations. This is sometimes true for important fish farming or fishing areas where high economic losses are claimed as otter damages, especially in Central Europe carp (Cyprinus carpio) raising pond areas (Kranz, 1994). With the decline of sea stocks worldwide, the importance of aquaculture activities, particularly in those regions where fish are an important food source for humans, has gained high economic relevance. This has been acknowledged through EU incentives to this economic activity, as in the case of the Mediterranean region, where fish farms can be found in both inland and coastal areas. The region, however, is also rich in fish-eating predators and farmed fishes are highly prone to predation, leading to conflicts between production and conservation interests.

Freshwater farm units in Portugal rear mainly trout, both for food production and stocking for recreational fisheries. As for coastal fish farming it can be traced back to the beginning of the 1980's, when most salt ponds were abandoned (the country was one of the most important salt producers up to the 1970's; IPIMAR, 1994) and converted to rear fish (Fig. 4)

Otters being widespread, conflict with farmers is inevitable. This led Portugal to be one of the eight European countries that, during a four-year period, developed a procedural framework for action plans aimed to reconcile such conflict (FRAP - Framework for Biodiversity Reconciliation Action Plans - EU Contract EVK2-CT-2002-00142).

On an early phase of the project, the distribution pattern of fish farms was analysed in relation to otter distribution, aiming to understand the perceived conflict at national level (Santos-Reis et al., 2007). As a second step, focal study sites were selected, both in inland and coastal areas, to evaluate how otters used fish farms. On the River Côa (central Portugal), research focused on river trout predation and the effects of a surplus source of trout on otter diet (Marques et al., 2007). For coastal areas, 14 fisheries spread in the estuary of the River Sado (SW Portugal) were monitored using an integrated approach that combined ecological data (otter visiting rates to fish farms, reared fish consumption vs. fish availability) with a socio-economic evaluation (available policies and instruments, stakeholders discourse analysis), to assess the

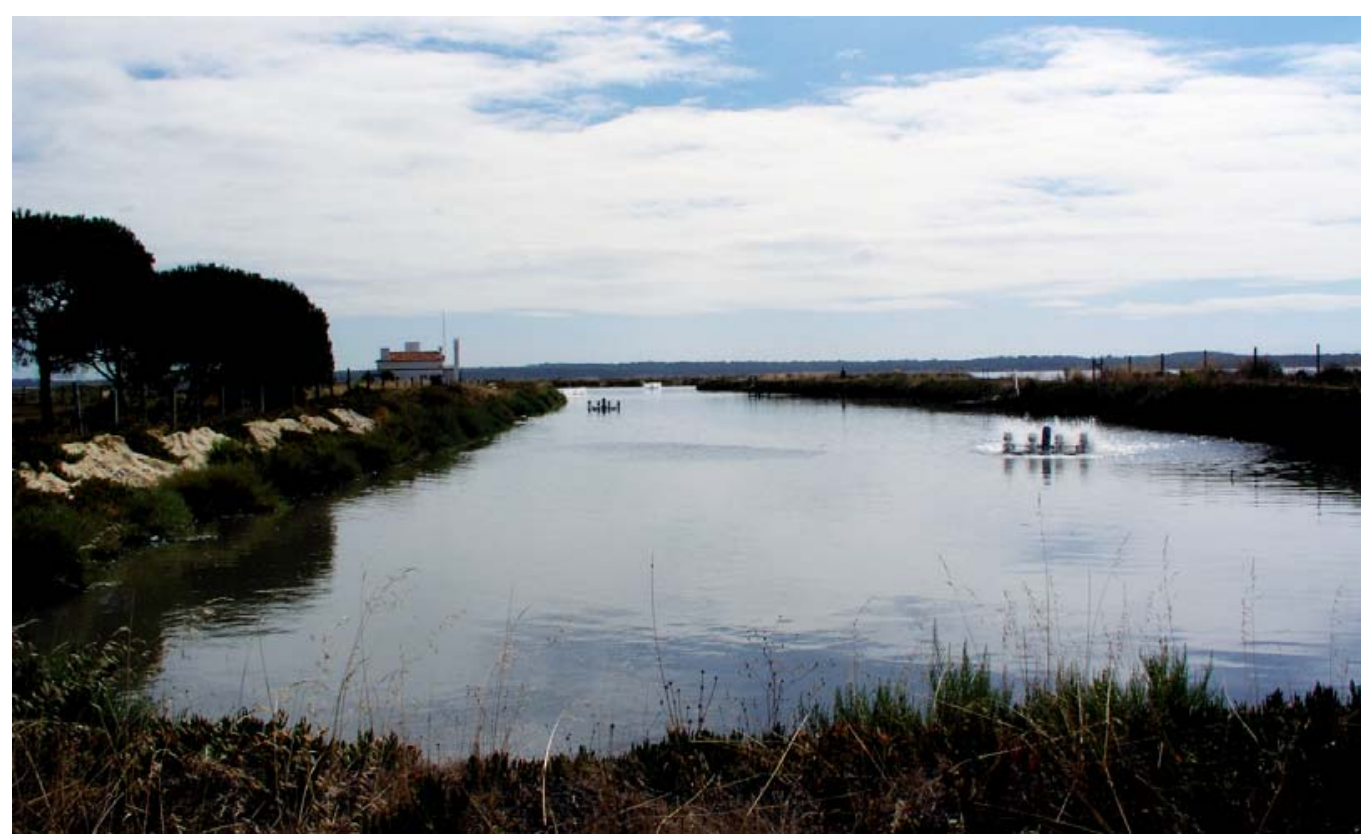

Fig. 4 - Marine fish farm in river Sado estuary, Portugal (photo: Teresa Sales-Luís).

Fig. 4. - Piscifactoría Marina en el estuario del río Sado, Portugal (foto: Teresa Sales-Luís). 
real and perceived (by fish farmers) impact of otters on fish production. Otter visiting rates to fish farms were assessed and related to otter diet, landscape factors and other resources availability (Freitas et al., 2007; Sales-Luís et al., 2009).

Results showed that otters frequently used fish farming areas and fish farmers perceived them as a problem, using different methods of deterrence (e.g. fencing, and dogs) or direct persecution (trapping, shooting or even poisoning) to reduce the predator's impact (Santos et al., 2006; Freitas et al., 2007; Sales-Luís et al., 2009).

Consumption of commercial species by otters was confirmed in both inland and coastal areas, but the impact, and therefore the potential for reconciliation, differed (Sales-Luís et al., 2011). Due to the seasonal constancy in the availability of trouts at Côa inland farm, the observed otter specialization in rainbow trout represents an extreme opportunistic behaviour, suggesting the need of an effective mitigation strategy (Marques et al., 2007). At Sado estuary, results indicate that although the conflict perceived by fish farmers has an ecological basis, there are large gaps between effective and perceived predation (Freitas et al., 2007). Furthermore, distance to rivers and refuge areas were identified as key landscape features promoting damage (Sales-Luís et al., 2009). This suggests different reconciliation strategies in both farm types which may vary from mitigation, to compensation and educational efforts. Moreover these results provide a management tool in landscape planning, as high risk farms can be identified and selectively protected (Sales-Luís et al., 2011; Santos-Reis et al., 2013).

\section{Otters and non-native species}

The introduction and invasion of non-native species are known to have impacts on both local prey and predators and are therefore considered a threat to biodiversity of conservation concern.

Otter diet is driven by prey availability. In Portugal, the increasing abundance and distribution of non-native fish species (e.g. Ribeiro et al., 2008) has been accompanied by a shift in otter diet from native to non-native fish species. As said above, otter diet in reservoirs is dominated by non-native species (Pedroso, 2012), since these species dominate the fish assemblages in reservoirs (Collares-Pereira et al. 2000; Filipe et al., 2004; Ribeiro et al., 2008). In this case, non-native species represent an opportunity for otter to feed during periods of drought. Nevertheless, in some studies, non-native species, such as Lepomis gibbosus (Linnaeus, 1758) were reported to be used less than expected in both Portugal (Sales-Luís et al. 2007; Pedroso, 2012) and Spain (Blanco-Garrido et al. 2008). Overall, diet studies suggest that, wherever available, native freshwater fishes are still the preferred prey of otters (Prenda \& Granado-Lorencio, 1995).

The American crayfish was introduced in Southwestern Iberia in the 1970's and has expanded northwards in Portugal (Ramos \& Pereira, 1981). In spite of its impact on amphibians (Cruz \& Rebelo, 2007), it has been shown to have positive effects on native predators (Tablado et al., 2010). The recovery of the otter in Spain, after the decline suffered by the species in the 1970s, was apparently partly related to the expansion of the crayfish (Ruiz-Olmo \& Delibes, 1998).

The American mink Neovison vison (Schreber, 1777) invaded Portugal in the 1980's, originating from mink farms in Galicia (Vidal-Figueroa \& Delibes, 1987) and has been expanding its range from Northwest towards the south. It is now present in the majority of the region's hydrographic basins: Minho, Lima, Neiva, Cávado, Ave and Sousa (Rodrigues et al., 2013). Using the same food and habitat resources, the mink is considered a potential competitor for otters (Bonesi \& Macdonald, 2004). Several studies indicate resource, spatial or temporal partitioning as the likely mechanisms favouring their coexistence. Competition, specifically for fish, is assumed to be asymmetrical in favour of the otter. Dietary shifts of American mink caused by competition with the otter are described by several authors (e.g. Bonesi et al., 2004). The American crayfish, being a prey for both mink and otters, might reduce food competition among the species and hence favour the spread of the mink.

\section{Otters and antimicrobial resistant bacteria}

There is a growing public concern for wildlife welfare but also a human medical interest in zoonosis. Biologists are interested in using wild animals as indicators of environmental pollution, while veterinaries are interested in the role wildlife may have as reservoir of infection and antimicrobial resistant bacteria (Simpson, 2000). In spite of all this, little is known about the role of free-ranging wild animals as potential vectors of pathogenic bacteria and antimicrobial resistance determinants, as well as the role of antimicrobial resistant pathogens in wildlife health.

Since otters are constantly in direct contact with water and land, also used by farm animals and man, ecological studies on their microflora are extremely relevant. In Portugal, work by Oliveira et al. (2008, 2009, 2010, 2011) and Semedo-Lemsaddek et al. (2013) has shown high levels of resistance in bacterial isolates from fecal microbiota (e.g Salmonella, Aeromonas, enterococci) of free-living otters. Of particular concern is the isolates multiresistant profile, defined as the resistance to more than one antimicrobial class. Results suggest that antimicrobial resistant bacterial strains may also be selected by environmental exposure to antimicrobial agents, analysed spraints possibly deriving from otters that had probably been exposed in their aquatic habitats to antimicrobial drugs from animal and human wastes (Cole et al., 2005; Sayah et al., 2005; Salyers and Shoemaker, 2006; Skurnik et al., 2006). Also, little is known about the clinical significance of otter bacterial diseases and their impact on the overall otter populations.

Characterization of the antimicrobial resistance profile of zoonotic and indicator bacteria may contribute to evaluate the potential of resistance genes transmission to the 
environment contaminated by humans and domestic and wild animals (Sayah et al., 2005). This studies allow to monitor selective pressure from drug therapeutic use and misuse in human and veterinary medicine or prophylaxis and metaphylaxis practices in farm animals. This is the frame of research conducted where in the future the circulation of genetic determinants, their diffusion pathways and ultimately their impact upon public health will be approached. Moreover, bacteriological and virulence patterns will be interpreted under different ecological, agro-pastoral and landscape structures to allow to identify the determinants involved in the maintenance, circulation and/or promotion of those pathogenic agents in the environment. Bacteria clonality and virulence traits should be taken upon consideration in risk assessment and decision support for intervention, management and conservation of wildlife, particularly in environments with high cattle density.

\section{OTTER CONSERVATION AND RESEARCH NEEDS \\ Threats}

Climate changes, bank side vegetation alteration, water pollution, water and sediment extraction, prey disturbance and exploitation and human disturbance are major disrupting factors for otters (Mason \& MacDonald, 1986; Trindade et al., 1998; Kruuk, 2006).

In Portugal, especially in the Southern Mediterranean part, most streams have an intermittent regime and dry out partially or completely during summer. This stress factor is surely demanding for otter populations and enlarges any additional impact factor that man may impose (Beja, 1992; Matos, 1999; Basto, 2006; Ruiz-Olmo \& Jiménez, 2009; Marques, 2010). Cianfrani et al. (2011) assessed climate change threats to the European otter using two climate change scenarios and several forecasting approaches and climate models. Results for the Mediterranean bioregion suggest that there will be a decrease in otter habitat suitability in the Iberian Peninsula, probably linked to a potential increase in droughts as the climate warms. As summers become hotter and longer (Santos et al., 2002), and water demand becomes higher (e.g., pumping water for agriculture), threats to otters will increase (Barbosa et al., 2003), as otters breed more frequently in complex and stable habitats (RuizOlmo \& Jimenez, 2009).

The destruction of the riparian vegetation (an ancient and persistent threat) is commonly associated with dam construction, river regulation (flood control), gravel and sand extraction and clear-cutting for expanding agricultural fields or favouring cattle accesses to water. These actions reduce drastically both cover and prey availability (ICN, 2006) and thus the overall carrying capacity of river habitats for otters.

Water pollution by toxic compounds, aggravated by bioaccumulation through the aquatic food chain, affects otter breeding success and cub survival (Olsson \& Sandegren, 1991; Roos et al., 2001) reducing its per se low natural recruitment (Conroy, 1992; Hauer et al., 2002). Al- though many toxic compounds have been banned (European Council Directive 79/117/EEC; EC Regulation No 850/2004) contamination from heavy metals and other sources of pollution is still a large scale phenomenon (Yamaguchia et al., 2003). Mercury and cadmium have been locally investigated in otters and their prey in the basin of the Sado river (Afonso, 1997; Henriques, 2010). Henriques (2010) revealing that cadmium contamination levels seem to follow a spatial pattern while those of mercury indicate a time pattern related to shifts in otter diet. Metal accumulation in American crayfish represents a potential threat to otters (Henriques, 2010). Monitoring aquatic poIlution is a crucial step in the management of aquatic and semi-aquatic wildlife. The European 2000 Water Framework Directive (WFD), by obliging Member States to setup or adapt monitoring procedures for gauging the status of waters, works in that direction and Portugal has already started to monitor its ten river basin districts although results are not yet easily available.

Human attraction for riverine, costal and wetland areas also poses a threat to otter populations. The growing demand for inland waters (reservoirs or lakes) to establish touristic settlements and infrastructures, increases human disturbance in these habitats (e.g. boats, camping and water sports). The same applies to coastal areas. As an example, the escalation of tourism pressure in the southwestern coast of Portugal (Costa Vicentina) may be especially deleterious to the otter population living in that area (Beja, 1996; ICN, 2006)

Accidental death by drowning in fike nets is not a major threat overall, but can be important locally. Otters are lured by the trapped fish and get caught in these funnel-shaped nets, drowning. This type of mortality is important in Finland and Denmark and in Portugal has been referred in two sea inlets, Castro Marim and Ria de Aveiro (Santos-Reis, 1983; ICN, 2006).

Road killing is one of the species main threats throughout Europe (Reuther \& Hilton-Taylor, 2004). As more roads are built and upgraded to sustain increasing traffic, the number of road kills increases, and mortality hotspots occur when roads run near lakes or reservoirs or cross over watercourses (Grilo et al., 2009).

\section{Species protection and monitoring}

Although, as mentioned previously, the otter status in Portugal is classified as "Least Concern" (Cabral et al., 2005), otter conservation is still mandatory in accordance with the Habitats Directive.

No nation-wide otter census has been carried out since the late 1990's. Nevertheless, it is expected that biodiversity monitoring will continue to occur under the Water Framework Directive, Habitats Directive and Natura 2000 Network, for which the otter is one of the target species. Additional information on the species distribution and ecology is expected to derive from Environmental Impact Assessments (EIA) of those structures that affect watercourses, such as hydroelectric infrastructures. 
The otter is listed in annexes II and IV of the Habitat Directive 92/43/EEC, implying that the species and its habitats, including connectivity corridors, must be considered in EIAs throughout the EU territory, and not only in the Special Areas for Conservation (SAC).

Regarding national conservation and management measures there are clearly defined guidelines for the species protection (ICN, 2006), to be applied especially in protected areas and Important Sites for Conservation (SICs) where the otter occurs. To maintain viable otter populations, as well as to ensure feeding, breeding and refuge habitats, the guidelines recommend to:

- Promote the conservation and recovery of native riparian vegetation;

- Promote safe havens along the waterways frequented by the species, maintaining bushes and other shrubs;

- Ensure flow regimes simulating natural variations and suitable to the ecological needs of the species;

- Maintain or improve water quality;

- Restrict the use of agro-chemicals, also adopting alternative techniques such as integrated biological methods;

- Monitor the ecological status of watercourses, with particular emphasis on the physic-chemical parameters of water (mainly in areas dominated by rice fields or near mining operations);

- Regulate the extraction of water, particularly during the months of lowest flow in areas important to otters for either breeding or food and shelter;

- Implement measures / preventive structures that reduce road kills;

- Promote the use of grids to prevent possible drowning in fike nets, at least in key areas for otter conservation;

- Improve the effectiveness of surveillance on illegal capture, killing and poisoning;

- Control urban and touristic expansion as to not affect the most sensitive areas for the species, particularly in coastal areas where human pressure is heavier;

- Include the otter as a target species when implementing environmental impact studies;

- Monitor compliance with mitigation and compensation measures of impacts and promote monitoring plans in environmental impact studies.

- Implement awareness campaigns for all the stakeholders involved in the management and use of aquatic and riparian environments (e.g. local authorities, fishermen, fish farmers, managers of aquatic environments).

\section{Knowledge gaps and future research}

While otter feeding habits are well known, our knowledge on the status of prey resources and the effects of drastic diet changes is somewhat undersized. This gap is of concern and should shape future research. The WFD may be a good step in that direction, as it establishes that the ecological status of water sheds is to be assessed based on the quality of the biological community, fish included.

The long-term effect of climate changes on otter population dynamics is still unknown. Repeated surveys at a fine-scale resolution are needed during the dry season as to disentangle the effects of on-coming changes in drought regimes, water pollution, and prey availability (Sales-Luís, 2011). Habitat changes occurred in the last 15 years suggest that a new nationwide otter survey should be planned and that surveys should be carried out periodically.

Although available data for Portugal suggest that otters are abundant, few attempts have been made to quantify population density and home-range size is still largely unknown.

Finally, otter bacterial diseases and their impact on the overall otter populations need further research.

Although in the near future Portuguese otters seem safe from major disrupting settings, we must keep in mind that any decline is a fast event, while recoveries are generally slow and not always successful, processes. Effective monitoring techniques are then needed to monitor periodically the status of the otter in Portugal.

\section{BIBLIOGRAPHY}

Afonso, O.M. 1997. Abordagem ao estudo do grau de contaminação por mercúrio da bacia do Rio Tejo e avaliação do possível impacte na população de lontra (Lutra lutra L., 1758) Graduation thesis. Faculdade de Ciências da Universidade de Lisboa. Lisboa.

Azinheira, C. 1998. Ecologia da lontra (Lutra lutra L. 1758): selecção de habitat. Graduation thesis. Universidade de Évora. Évora.

Barbosa, A.M., Real, R., Olivero J., Vargas, J.M. 2003. Otter (Lutra lutra) distribution modelling at two resolution scales suited to conservation planning in Iberian Peninsula. Biol. Conserv. 114: 377-387.

Barrinha, C.A.C. 2002. Análise da dieta da lontra (Lutra lutra Linnaeus, 1758) na área de regolfo de Alqueva e Pedrogão (SE Portugal). Graduation thesis. Faculdade de Ciências da Universidade de Lisboa. Lisboa.

Basto, M.S.P. 2006. Utilização de sistemas lênticos de pequenamédia dimensão pela lontra (Lutra lutra L.. 1758) no Sítio de Monfurado. Master thesis. Universidade de Evora. Evora.

Basto, M., Pedroso, N.M., Mira, A., Santos-Reis, M. 2011. Use of small and medium-sized water reservoirs by otters in a Mediterranean ecosystem. Anim. Biol. 60: 75-94.

Beja, P.R. 1989a. Estudo ecológico de Lutra lutra (Linnaeus, 1758) (Carnivora, Mustelidae) na costa sudoeste portuguesa. Graduation thesis. Faculdade de Ciências da Universidade de Lisboa. Lisboa.

Beja, P.R. 1989b. Coastal otters in southern Portugal. IUCN Otter Spec. Group Bull. 4: 2-7.

Beja, P.R. 1991. Diet of otters (Lutra lutra) in closely associated freshwater, brackish and marine habitats in southwest Portugal. J. Zool. 225: 141-152

Beja, P.R. 1992. Effects of freshwater availability on the summer distribution of otters Lutra lutra in the southwest coast of Portugal. Ecograhpy 15: 273-278. 
Beja, P.R. 1995a. Patterns of availability and use of resources by otters (Lutra lutra L.) in Southwest Portugal. PhD thesis. University of Aberdeen. Aberdeen.

Beja, P.R. 1995b. Structure and seasonal fluctuations of rocky littoral fish assemblages in south-western Portugal: Implications for otter prey availability. J. Mar. Biol. Ass. U.K. 75: 833-847.

Beja, P.R. 1996a. An analysis of otter Lutra lutra predation on introduced American crayfish Procambarus clarkii in Iberian streams. J. Appl. Ecol. 33: 1156-1170.

Beja, P.R. 1996b. Seasonal breeding and food resources of otters, Lutra lutra (Carnívora, Mustelidae), in south-west Portugal: a comparison between coastal and inland habitats. Mammalia 60(1): $27-34$

Beja, P.R. 1996c. Temporal and spatial patterns of rest-site use by four female otters Lutra lutra along the south-west coast of Portugal. J. Zool. London 239: 741-753.

Bernardo, J.M. 2008. Influência antropogénica na distribuição da lontra (Lutra lutra). Master thesis. Universidade de Aveiro. Aveiro.

Blanco-Garrido, F., Prenda, J., Narvaez, M. 2008. Eurasian otter (Lutra lutra) diet and prey selection in Mediterranean streams invaded by centrarchid fishes. Biol. Invasions. 10: 641-648.

Bocage, J.B. 1863 Liste des mamiferes et reptiles observés en Portugal. Rev. Mag. Zool. 5: 329-333.

Bonesi, L., Macdonald, D.W. 2004. Differential habitat use promotes sustainable coexistence between the specialist otter and the generalist mink. Oikos 106: 509-519.

Bonesi, L., Chanin, P., Macdonald, D.W. 2004. Competition between Eurasian otter Lutra lutra and American mink Mustela vison probed by niche shift. Oikos 106: 19-26.

Cabral, M.J., Almeida, J., Almeida, P.R., Dellinger, T., Ferrand de Almeida, N., Oliveira, M.E., Palmeirim, J.M., Queiroz, A.I., Rogado, L., Santos-Reis, M. 2005. Livro vermelho dos vertebrados de Portugal. Instituto da Conservação da Natureza. Lisboa.

Campos, M. 1993. Análise da situação actual da Lutra lutra (L. 1758) na Reserva do Estuário do Sado. Graduation thesis. Faculdade de Ciências da Universidade de Lisboa. Lisboa.

Cerqueira, L. 2005. Distribuição e ecologia alimentar da Lontra (Lutra lutra) em dois sistemas costeiros em Portugal. Master thesis. Universidade do Minho. Braga.

Chambel, I. 1997a. Situação actual da lontra (Lutra lutra) na Reserva Natural do Sapal de Castro Marim e Vila Real de Santo António. Instituto da Conservação da Natureza. Programa Life. Lisboa.

Chambel, I. 1997b. Aspectos da ecologia da lontra (Lutra lutra) na área do Parque Natural do Alvão. Graduation thesis. Faculdade de Ciências da Universidade de Lisboa. Lisboa.

Clavero, M., Blanco-Garrido, F., Prenda, J. 2004. Fish fauna in Iberian Mediterranean river basins: biodiversity, introduced species and damming impacts. Aquat. Conserv. 14: 575-585.

Cianfrani, C., Le Lay, G., Maiorano, L., Satizábal, H.F., Loy, A., Guisan, A. 2011. Adapting global conservation strategies to climate change at the European scale: The otter as a flagship species. Biol. Conserv. 144: 2068-2080.

Clavero, M., Ruiz-Olmo, J., Sales-Luís, T., Blanco-Garrido, F., Romero, R., Pedroso, N.M., Prenda, J., Santos-Reis, M., Narváez, M., Delibes, M. 2008. Lo que comen las nutrias ibéricas. In: La nutria en España. Veinte años de seguimiento de un mamífero amenazado. J.M. López-Martín, J. Jiménez (Eds.): 345-367. SECEM. Málaga.
Cole, D., Drum, D.J.V., Stallknecht, D.E., White, D.G., Lee, M., Ayers, S., Sobsey, M., Maurer, J.J. 2005. Free-living Canada Geese and Antimicrobial Resistance. Emerg. Infect. Dis. 11: 935-938.

Collares-Pereira, M.J., Cowx, I., Ribeiro, F., Rodrigues, J., Rogado, L. 2000. Threats imposed by water resource development schemes on the conservation of endangered fish species in the Guadiana River Basin in Portugal. Fisheries Manag. Ecol. 1-2: 167-178

Conroy, J.W.H. 1992. Otter mortality and survival. In: Proceedings of the national otter conference. Royal Society for Nature and Conservation. Cambridge.

Cruz, M.J., Rebelo, R. 2007. Colonization of freshwater habitats by an introduced crayfish, Procambarus clarkii, in Southwest lberian Peninsula. Hydrobiologia. 575: 191-201.

Farinha, N. 1995. Distribuição e ecologia da lontra (Lutra lutra Linnaeus, 1758) no Parque Natural de Montesinho. Graduation thesis. Faculdade de Ciências da Universidade de Lisboa. Lisboa.

Ferrand d'Almeida, F. 1980. Uber das Vorkommen des Fischotters in Portugal. In: Der Fischotter in Europe - Verbreitung, Bedrohung, Erhaltung. C. Reuther, A. Festetics, A. (Eds): 141-143. Oderhaus \& Gottingen. Selbsverlag.

Filipe, A.F., Marques, T.A., Seabra, S., Tiago, P., Ribeiro, F., Costa L., Moreira, D.A., Cowx, I.G. 2004. Selection of Priority Areas for Fish Conservation in Guadiana River Basin, Iberian Peninsula. Conserv. Biol. 18(1): 189-200.

Florêncio, E. 1993. O lagostim de rio (Procambarus clarkii Girard, 1852) como recurso alimentar da comunidade de carnívoros na Reserva Natural do Paúl do Boquilobo. Graduation thesis. Faculdade de Ciências da Universidade de Lisboa. Lisboa.

Florêncio, E. 1994. Distribuição e ecologia trófica da lontra (Lutra lutra L.) na bacia hidrográfica do rio Almonda. Instituto da Conservação da Natureza. Lisboa.

Foster-Turley, P., MacDonald, S., Mason, C. 1990. Otters: an action plan for their conservation. IUCN Species Survival Commission. IUCN. Gland.

Freitas, D. 1999. A dieta da lontra (Lutra lutra L.) ao longo da bacia hidrográfica do rio Tejo. Graduation thesis. Faculdade de Ciências da Universidade de Lisboa. Lisboa.

Freitas, D, Gomes, J., Sales Luis, T., Madruga, T., Marques, C., Baptista, C., Rosalino, L.M., Antunes, P., Santos, R., Santos-Reis, M. 2007. Otters and fish farms in the Sado estuary: ecological and socio-economic basis of a conflict. Hydrobiologia 587:51-62.

Garcia, J.C. 2006. Comportamento trófico da lontra (Lutra lutra Linnaeus, 1758) nas pisciculturas e áreas limítrofes do Estuário do Sado. Graduation thesis. Faculdade de Ciências da Universidade de Lisboa. Lisboa.

Gomes, N. 1998. Distribuição e ecologia trófica da lontra (Lutra lutra) na Ria de Aveiro. Master thesis. Faculdade de Ciências da Universidade do Porto. Porto.

Gomes, N., Alves, P. Henriques, J., Ramos, A. Tavares, L. 1989. Contribution à l'étude du régime alimentaire de la loutre (Lutra lutra) au Portugal. Cienc. Biol. 9(1/2): 47-54

Grilo, C. Bissonette, J., Santos-Reis, M. 2009. Spatial-tempora patterns in Mediterranean carnivore road casualties: Consequences for mitigation. Biol. Conserv. 142: 301-313.

Hauer, S., Ansorge, H., Zinke, O. 2002. Reproductive performance of otters Lutra lutra (Linnaeus, 1758) in Eastern Germany: low reproduction in a long-term strategy. Biol. J. Linnean Soc. 77 329-340.

Henriques, J.F. 2010. Contaminação de cadeias tróficas em zonas húmidas: implicações para a conservação. Master thesis. Faculdade de Ciências da Universidade de Lisboa. Lisboa. 
Houston, A.I., McNamara, J.M. 1994. Models of diving and data from otters: comments on Nolet et al. (1993). J. Anim. Ecol. 63 1004-1006

ICN 2006. Lutra lutra. Fauna. Ficha de caracterização ecológica e de gestão. Plano Sectorial da Rede Natura 2000. Instituto da Conservação da Natureza. Lisboa.

ICN 2008. Lutra lutra. Report on the main results of the surveillance under article 11 for annex II, IV and V species (Annex B). Instituto da Conservação da Natureza. Lisboa.

IPIMAR 1994. Seminário sobre Recursos Haliêuticos, Ambiente, Aquacultura e Qualidade do Pescado da Península de Setúbal. I.P.I.M. Lisboa. (Publicações avulsas do IPIMAR; 1).

Kranz, A. 1994. Otters recovering - threats increasing. IUCN Otter Spec. Group Bull. 10: 28-30.

Kruuk, H. 1995. Wild otters. Predation and population. University Press. Oxford.

Kruuk, H. 2006. Otters ecology behaviour and conservation. Oxford University Press. Oxford.

Kruuk, H., Conroy, J.W.H., Glimmerveen, U., Ouwerkerk E.J. 1986. The use of spraints to survey populations of otter Lutra lutra. Biol. Conserv. 35: 187-194.

Lopes, M. 1999. Situação da lontra (Lutra lutra Linnaeus, 1758) no Parque Natural do Guadiana. Graduation thesis. Faculdade de Ciências da Universidade de Lisboa. Lisboa.

Macdonald, S.M. 1983. The status of the otter (Lutra lutra) in the British Isles. Mammal Rev. 13: 11-23.

Macdonald, S.M., Mason, C.F. 1982. The otter Lutra lutra in central Portugal. Biol. Conserv. 22: 207-215.

MacDonald, S.M., Mason, C.F. 1994. Status and conservation needs of the otter (Lutra lutra) in the Western Palaeartic. Council of Europe Press. Nature and Environment. Strasbourg.

Macdonald, S.M. 1994. Meeting of European Section OSG. IUCN Otter Spec. Group Bull. 10: 10-14

Magalhães, M.F., Beja P., Canas, C., Collares-Pereira, M.J. 2002 Functional heterogeneity of dry-season refugia across a Mediterranean catchment: the role of habitat and predation. Fresh. Biol. 47: 1919-1934

Magalhães, M.F., Beja, P., Schlosser, I.J., Collares-Pereira, M.J. 2007. Effects of multi-year droughts on fish assemblages of seasonally drying Mediterranean streams. Fresh. Biol. 52: 14941510

Marques C. 2010. Depleção de presas pela lontra euroasiática (Lutra lutra) numa ribeira mediterrânica durante a seca estival. Master thesis. Universidade de Évora. Évora.

Marques, C., Rosalino, L.M., Santos-Reis, M. 2007. Otter predation in a trout fish farm of central-east Portugal: preference for 'fast-food'? River Res. Appl. 23: 1147-1153.

Mason, C.F., Macdonald, S.M. 1986. Otters, conservation and ecology. Cambridge University Press. Cambridge.

Matos, H. 1999. Aspectos da ecologia da lontra (Lutra lutra) em ribeiras intermitentes num sector da bacia do rio Sado (SO Portugal). Graduation thesis. Faculdade de Ciências da Universidade de Lisboa. Lisboa.

Michelot, J.L., Bendelé, R. 1995. Statut de la loutre dans le bassin du Rhône et le Département de l'Ardèche. Cah. Ethol. 15: 223-232.

Novais, A. 2005. Ecologia da Lontra (Lutra lutra L.): chaves de identificação de peixes consumidos, dieta no rio Paiva e actividades científicas e investigativas no ensino. PhD thesis. Universidade de Coimbra. Coimbra.
Oliveira, M., Pedroso, N., Sales-Luís, T., Santos-Reis, M., Tavares, L., Vilela, C.L. 2009. Evidence of antimicrobial resistance in Eurasian otter (Lutra lutra Linnaeus, 1758) fecal bacteria in Portugal. In: Wildlife: Destruction, Conservation and Biodiversity. J.D. Harris, P.L. Brown (Ed.): 201-221. Nova Science Publishers. Hauppauge, New York.

Oliveira, M., Pedroso, N.M., Sales-Luís, T, Santos-Reis, M., Tavares, L. Vilela, C.L. 2010. Antimicrobial resistant Salmonella isolated from Eurasian otters (Lutra lutra Linnaeus, 1758) in Portugal. J. Wildl. Dis. 46(4): 1257-1261.

Oliveira, M., Sales-Luís, T., Duarte, A., Nunes, S.F., Carneiro, C. Tenreiro, T., Tenreiro, R., Santos-Reis, M., Tavares L., Vilela, C.L. 2008. First assessment of microbial diversity in faecal microflora of Lutra lutra in Portugal. Eur. J. Wildl. Res. 54: 245-252.

Oliveira, M., Sales-Luís, T., Semedo-Lemsaddek, T., Ribeiro, T., Pedroso, N.M., Tavares, L., Vilela, C.L 2011. Antimicrobial Resistant Aeromonas Isolated from Eurasian Otters (Lutra lutra Linnaeus, 1758) in Portugal. In: Animal Diversity, Natural History and Conservation Vol 1. V. Gupta (Ed.): 123-144. Daya Publishing House. Delhi.

Olsson, M., Sandegren, F. 1991. Otter survival and toxic chemicals: implication for otter conservation programmes. Habitat 6 : 191-200.

Palomo, L.J., Gisbert, J., Blanco, J.C. 2007. Atlas \& Libro Rojo de los Mamiferos Terrestres de España. Dirección General para la Biodiversidad. SECEM-SECEMU. Madrid.

Pedrosa, M. 2000. Aspectos da ecologia da lontra (Lutra lutra) em ambientes aquáticos de Vilamoura (sul de Portugal). Graduation thesis. Faculdade de Ciências da Universidade de Lis boa. Lisboa.

Pedroso, N.M. 1997. A lontra (Lutra lutra Linnaeus, 1758) na barragem da Aguieira. Graduation thesis. Faculdade de Ciências da Universidade de Lisboa. Lisboa.

Pedroso, N.M., Sales-Luís, T., Santos-Reis, M. 2007. Use of Aguieira Dam by Eurasian otters in Central Portugal. Folia Zool. 56(4): 365-377

Pedroso, N.M. 2012. Otters and Dams in Mediterranean Habitats: a Conservation Ecology Approach. PhD thesis. Universidade de Lisboa. Lisboa.

Pedroso, N.M., Marques, T.A., Santos-Reis, M. 2013. The response of otters to environmental changes imposed by the construction of large dams. Aquatic Conserv: Mar. Freshw. Ecosyst 24(1): 66-80

Pedroso, N.M., Santos-Reis M. 2006. Summer Diet of Eurasian Otters in Large Dams of South Portugal. Hystrix. 17(2): 117-128.

Pedroso, N.M., Santos-Reis, M., 2009. Assessing otter presence in dams: A Methodological proposal. IUCN Otter Spec. Group Bull. 26: 97-109.

Prenda, J., López-Nieves, P., Bravo, R. 2001. Conservation of otter (Lutra lutra) in a Mediterranean area: the importance of habitat quality and temporal variation in water availability. Aquat Conserv. 11: 343-355.

Prenda, J., Granado-Lorencio, C. 1995. The relative influence of riparian habitat structure and fish availability on otter Lutra lutra L. sprainting activity in a small Mediterranean catchment. Biol. Conserv. 76: 9-15.

Quaglietta, L., Martins, B.H., De Jongh, A., Mira, A., Boitani, L. 2012 A low-cost GPS GSM/GPRS telemetry system: performance in stationary field tests and preliminary data on wild otters (Lutra lutra). PloS one 7(1): e29235.

Quaglietta, L., Fonseca, V.C., Hájková, P., Mira, A., Boitani, L. 2013. Fine-scale population genetic structure and short-range sex-biased dispersal in a solitary carnivore, Lutra lutra. J. Mam mal. 94(3): 561-571. 
Ramos, M.A., Pereira, T.M. 1981. Um novo Astacidae para a fauna Portuguesa Procambarus clarkii (Girard, 1852). Bol. Instituto Nac. Investig. e Pescas: 6: 37-47.

Reuther, C. 1977. Der Fischotter, Lutra lutra (Linné, 1758) - Biologie. Status und Schutz am Beispiel des Harzes. Mitteilungen aus dem Ergänzungsstudium Ökologische Umweltsicherung Vol. 3. Witzenhausen.

Reuther, C., Dolch, D., Green, R., Jahrl, J., Jefferies, D., Krekemeyer, A., Kucerova, M., Madsen, A.B., Romanowski, J., Röche, K., Ruiz-Olmo, J., Teubner, J., Trindade, A. 2000. Surveying and Monitoring Distribution and Population Trends of the Eurasian Otter (Lutra lutra). Guidelines and Evaluation of the Standard Method Surveys as recommended by the European Section of the IUCN/SSC Otter Specialist Group. Habitat 12: 1-148.

Reuther, C., Hilton-Taylor, C. 2004. Lutra lutra. In: IUCN 2007. 2007 IUCN Red List of Threatened Species. Disponible en Web: www.iucnredlist.org.

Ribeiro, F., Elvira, B., Collares-Pereira, M.J., Moyle, P.B. 2008. Life-history traits of non-native fishes in Iberian watersheds across several invasion stages: a first approach. Biol. Invasions. 10(1):89-102.

Robitaille, J.F., Laurence, S. 2002. Otter, Lutra lutra, occurrence in Europe and in France in relation to landscape characteristics. Anim. Conserv. 5: 337-344.

Roos, A., Greyerz, E., Olsson, M., Sandegren, F. 2001. The otter (Lutra lutra) in Sweden - population trends in relation to (RDDT and total PCB concentrations during 1968-1999. Environ. Pollut. 111: 457-469.

Ruiz-Olmo, J., Delibes, M. 1998. La nutria en españa ante el horizonte del año 2000. SECEM. Málaga.

Ruiz-Olmo, J., Jiménez, J. 2009. Diet diversity and breeding of top predators are determined by habitat stability and structure: a case study with the Eurasian otter (Lutra lutra L.). Eur. J. Wildl. Res. 55 (2): 133-144.

Ruiz-Olmo, J., Lopez-Martin, J.M., Palazon, S. 2001. The influence of fish abundance on the otter (Lutra lutra) populations in Iberian Mediterranean habitats. J. Zoology, London 254: 325-336.

Sales-Luís, T. 1998. Análise comparativa da utilização dos recursos de uma barragem e seus tributários pela lontra - Barragem da Aguieira. Graduation thesis. Faculdade de Ciências da Universidade de Lisboa. Lisboa.

Sales-Luís, T. 2011. Patterns of otter (Lutra lutra) distribution and man-otter conflicts in river Sado basin: conservation implications. $\mathrm{PhD}$ Thesis. Lisbon University. Lisbon.

Sales-Luís, T., Bissonette, J.A. Santos-Reis, M. 2012. Conservation of Mediterranean otters: the influence of map scale resolution. Biodiver. Conserv. 21: 2061-2073.

Sales-Luís, T., Freitas, D., Santos-Reis, M. 2009. Key landscape factors for Eurasian otter Lutra lutra visiting rates and fish loss in estuarine fish farms. Eur. J. Wildl. Res. 55: 345-355.

Sales-Luís, T., Freitas, D., Rosalino, L.M., Marques, C., SantosReis, M. 2011. Fish farms and otter predation: the role of environment and management options. In Fish Farms: Management, Disease Control and the Environment. G.L. Andrews, L.A. Vexton (Eds.). Nova Science Publishers. Hauppauge, New York.

Sales-Luís T., Pedroso N.M., Santos-Reis M., 2007. Prey availability and diet of the Eurasian otter (Lutra lutra) on a large reservoir and associated tributaries. Can. J. Zool. 85(11): 1125-1135.

Salqueiro, V. 2009. Variabilidade temporal na disponibilidade de presas e dieta da lontra em ribeiras intermitentes na serra de Grândola: implicações de conservação. Master thesis. Faculdade de Ciências da Universidade de Lisboa. Lisboa.
Salyers, A., Shoemaker, N.B. 2006. Reservoirs of antibiotic resistance genes. Anim. Biotechnol. 17: 137-146.

Santos, F.D., Forbes, K., Moita, R. 2002. Climate Change in Portugal: Scenarios, Impacts and Adaptation Measures. SIAM Project. Gradiva. Lisboa.

Santos, M.J., Pedroso, N.M., Ferreira, J.P., Matos, H.M., SalesLuís, T., Pereira, I., Baltazar, C., Grilo, C., Cândido, A.T., Sousa I., Santos-Reis, M. 2008. Assessing dam implementation impact on threatened carnivores: the case of Alqueva in SE Portugal. Environ. Monit. Assess. 142: 47-64.

Santos, R. Antunes, P. Baptista, G., Mateus, P., Madruga, L. 2006. Stakeholder participation in the design of environmental policy mixes. Ecol. Econ. 60(1): 100-110.

Santos-Reis, M., Ferreira, J.P. Pedroso, N.M., Baltazar, C. Matos, H., Pereira, I., Grilo, C., Sales-Luís, T., Santos, M.J., Cândido, A.T. Sousa, I., Rodrigues, M. 2003. Projectos de monitorização de mamíferos: monitorização de carnívoros. Relatório Final, $2^{\mathrm{a}}$ Fase de Monitorização. Programa de Minimizacão para o Património Natural da área de regolfo de Alqueva e Pedrógão. Centro de Biologia Ambiental - Centro de Estudos da Avifauna Ibérica. Lisboa.

Santos-Reis, M., Freitas, D., Sales-Luís, T. 2007. Man-otter conflict in Portuguese fisheries: introducing a comprehensive approach. In: Proceedinds of the European Otter Survival Fund J.W.H. Conroy, J. Gutleb, J. Ruiz-Olmo, G.M. Yoxon. (Eds). Isle of Skye, UK. (J. Intern. Otter Survival Fund ; 2).

Santos-Reis, M., Trindade, A., Beja, P.R. 1995. Situation et état des recherches sur la loutre au Portugal. Cah. Ethol. 15 (2-4): 181-194.

Santos-Reis, M. 1983. Present situation and conservancy of the river otter (Lutra lutra L. 1758) in Portugal. 3rd International Otter Symposium. Strasburg.

Santos-Reis, M., Santos, R., Antunes, P., Sales-Luís, T., Gomes, J., Freitas, D., Madruga, L. (2013). Reconciliation of the conflict between otters and fish farmers: lessons from Sado estuary in Portugal. In: Human Wildlife Conflicts in Europe Fisheries and Fish-eating Vertebrates as a Model Case. R. Klenke, I. Ring, A. Kranz, N. Jepsen, F. Rauschmayer, K. Henle (Eds): 49-78. Springer. Berlin.

Sayah, R.S., Kaneene, J.B., Johnson, Y., Miller, R. 2005. Patterns of Antimicrobial Resistance Observed in Escherichia coli Isolates Obtained from Domestic- and Wild-Animal Fecal Samples, Human Septage, and Surface Water. Appl. Environ. Microbiol. 71: 1394-1404.

Seabra, A.F. 1900. Mamíferos de Portugal no Museu de Lisboa. Jornal Ciênc. Matemáticas, Físicas Nat. 6: 90-115.

Seabra, A.F. 1924. Études sur la faune mammalogique du Portugal. Note sur la synonymie des mammifères carnivores. Mem. Estudos Zoológicos da Univ. Coimbra 3: 1-16.

Semedo-Lemsaddek, T., Nóbrega, C.S., Ribeiro, T., Pedroso, N.M., Sales-Luís, T., Lemsaddek, A., Tenreiro, R., Tavares, L., Vilela, C.L., Oliveira, M. 2013. Virulence traits and antibiotic resistance among enterococci isolated from Eurasian otter (Lutra lutra). Vet. Microbiol. 163: 378-382.

Silva, C. 1999. Predação por lontra, Lutra lutra L., em habitats estivais de uma ribeira intermitente Mediterrânica. Graduation thesis. Universidade do Algarve. Faro.

Simões, P. 1977. Uma população de lontras do litoral português. Boletim da LPN. 16: 17-19.

Simões-Graça, M.A., Ferrand d'Almeida, F. 1983. Contribuição para o conhecimento da lontra (Lutra lutra L.) num sector da bacia do Rio Mondego. Cienc. Biol. 5: 33-42.

Simpson, V.R. 2000. Veterinary advances in the investigation of wildlife diseases in Britain. Res. Vet. Sci. 69: 11-16. 
Skurnik, D., Ruimy, R., Andremont, A., Amorin, C., Rouquet, P., Picard, B., Denamur, E. 2006. Effect of human vicinity on antimicrobial resistance and integrons in animal fecal Escherichia coli. J. Antimicrob. Chemother. 57: 1215-1219.

SNPRCN 1990. Livro Vermelho dos Vertebrados de Portugal: Vol. I - Mamíferos, Aves, Répteis e Anfíbios. Secretaria de Estado do Ambiente e Defesa do Consumidor. Lisboa.

Sousa, M.N. 1995. Ecologia e conservação da lontra (Lutra lutra Linnaeus, 1758) na área do Parque Natural da Serra da Estrela. Gradution thesis. Faculdade de Ciências da Universidade de Lisboa. Lisboa.

Rodrigues, D., Simões, L., Mullins, J., Goebel, J., Mendes, R., Moreira, F., Duarte, R., Goncalves, S., Lampa, S., Fernandes, C., Rebelo, R. Santos-Reis, M. 2013. The American mink (Neovison vison) in Portugal: current status and ecological insights. Wild Musteloid Conference: WildCRU and IUCN/SSC Otter and Small Carnivore Specialist Group. Oxford. 18-12 March 2013.

Tablado, Z., Tella, J., Sanchez-Zapata, J., Hiraldo, F. 2010. The Paradox of the Long-Term Positive Effects of a North American Crayfish on a European Community of Predators. Conserv. Biol. 24: $1230-1238$.

Trigo, M.I. 1994. Predação por lontra (Lutra lutra Linnaeus, 1758 ) em pisciculturas do estuário do Mira. Graduation thesis. Faculdade de Ciências da Universidade de Lisboa. Lisboa.
Trindade, A. 1987. A lontra in Alguns Vertebrados do Parque Natural da Peneda-Gerês. Serviço Nacional de Parques, Reservas e Conservação da Natureza. Lisboa.

Trindade, A. 1989. Some research projects on otters in Portugal Habitat 6: 263-264.

Trindade, A. 1996. A lontra Lutra lutra na Reserva Natural do Estuário do Sado. DSCN/DEP. (Estudos de Biologia e Conservação da Natureza; 18).

Trindade, A., Farinha, N., Florêncio, E. 1998. A distribuição da lontra Lutra lutra em Portugal: situação em 1995. DSCN/DEP. (Estudos de Biologia e Conservação da Natureza; 28).

Trindade, G. 2002. A lontra (Lutra lutra Linnaeus, 1758) na bacia hidrográfica do Sado: distribuição e análise dos arrozais como fonte de recursos tróficos. Graduation thesis. Faculdade de Ciências da Universidade de Lisboa. Lisboa.

Vidal-Figueroa, T., Delibes, M. 1987. Primeros datos sobre el visón americano (Mustela vison) en el Suroeste de Galicia y Noroeste de Portugal. Ecologia 1:145-152.

Yamaguchia, N., Gazzardb, D., Scholeyc, G., Macdonald, D.W 2003. Concentrations and hazard assessment of PCBs, organochlorine pesticides and mercury in fish species from the upper Thames: River pollution and its potential effects on top predators. Chemosphere 50(3): 265-273. 